\title{
ORIGINS OF INDIAN CHRISTIANS \\ IN \\ INDIA
}

\section{J. Rabindra Daniel}

An attempt is made in this paper to trace the origins of Indian Christians in India from the first century to the twentieth century of the Christian era. Indian society over the last two thousand years had been subjected to foreign conquest. It consequently under went various changes in the spheres of religion, trade, culture and politics.

The Indian Society was predominantly Hindu until the 7th century A.D. Its marriage, caste and other social institutions were more or less intact with the beginnings of Muslim conquest in the middle half of the: 7th century (647 A.D.) Indian civilization began to be pervaded with a new feature, i.e. one of Islamic civilization. Its' impact was more pronounced in North India. Many Indians responded to Islam. Muslim rule began to dwindle with the advent of the Europeans (Portuguese) in 1498 and subsequently the British. The British ruled India a couple of centuries until 1947 when India emerged as a complete independent nation.

Set against this vibrant background Christianity took roots in India as a foreign religion from the first Century A.D. but became more accentuated only after the arrival of the Portuguese in 1498 and subsequently the British. In order to have a clearer picture of the evolution of Christianity in India over time, this paper will be discussed along topic/chronology lines.

\section{Early History - Before 1500 A. D.}

A Christian Community existed in India from the first century of the Christian era, and its population was later increased by the missionary activities of the Portuguese. However, the present Christian population is to a great extent, a result of the substantial conversion to christianity in the nineteenth and twentieth centuries.

There is not much concrete historical evidence to support the fact that the advent of Christianity into India took place in the first century of the Christian era. Nevertheless, legends and travel accounts show the presence of Christians. Many of these legends describe largely the life and works of St. Thomas the Apostle.

There is a tradition preserved by the Syrian church in Travancore that claims St. Thomas as its founder and dates his arrival in the year A.D. $52^{1}$. The apostle, it appears came to visit the Jews of Malabar to spread the news of the Messiah. St. Thomas not only preached to his fellow Jews but courageously preached the gospel to the people of Malabar as well. It is said that within a short spell of time Thomas was able to convert a large number of people in South India including rulers and high caste Brahmins. The miraculous power of this apostle 
convinced many into accepting Christianity.

Thomas did most of his missionary work in the kingdom of Chera although there were two other kingdoms in South India at that time. They are the Pandya and Chola kingdoms. ${ }^{2}$ After preaching in the Chera kingdom he went to China for a short spell and returned to Malabar. He then crossed the Western Ghats to preach the Gospel in Tamil Nadu. The Apostle's labours in the Tamil kingdom produced good results too.

The popularity of St. Thomas amongst the folks was not to his advantage in the long run. The Brahmins who were the religious leaders feared a diminution of their supreme religious position. They naturally reacted against the Apostle who was beginning to have a grip on the masses. Consequently, false accusation and open opposition to the saint and his teachings became common. For instance, he was accused of being a father of an illegitimate child. Finally, he was killed and buried in Mylapore and that place has since become a centre of pilgrimage for Indian Christians.

It can be said then that the first churches in India were founded by the Apostle Thomas. Although inferences have been made from folk tales and legends, there were also other logical and convincing circumstances ascertaining the presence of St. Thomas and the early christians. First, India had commercial links with the West especially Rome. Active commerce had already developed between South India and the West in the first century A.D. as a result of the epoch making discovery of sea-routes to the east by Hippalus in A.D.47. If ships are driven by the monsoon winds it would be possible to traverse the Arabian Sea. This would enable the navigators to sail to whatever post they desired on the West Coast of the Indian Peninsula, Cochin and Goa. According to Stephen Neill $^{3}$ the discoveries of hordes of Roman coins all over South India, and still more strikingly of a Roman commercial settlement of the first century A.D. on the Southeast coast of India, at Arikkamedu in the neighbourhood of Pondichery, make it clear that commerce between the Roman Empire and South India was transacted on a grand scale. If Thomas was at any time in Egypt, there was nothing to prevent him from taking a ship and transporting himself to India.

Secondly, there is literary evidence to show that there was a connection between Thomas and India from the heretical Acts Of Thomas, a work of the third century. ${ }^{4}$ Here the world was divided for the Apostles to go and preach and India fell to the lot of Thomas. Much is told of the adventures of Thomas in India. Third, St Thomas founded the seven churches of Cranagore, Palur, North Palur, South Pallipuram, Niranan, Nellakul and Quilon. ${ }^{5}$ Some of the churches have accounts of their foundation that are far from being mere tales. It is reported that in Niranan, a hamlet to the South of Tiruvalla, there is a local tradition that most of the Namburi Brahmins were converted by Thomas. Liet. Connor found an inscription at Niranan which stated that the church was enlarged in A.D. 1259. A. similar story comes from Palur that St. Thomas converted some Brahmin families of the place while others who refused to be converted left the place. They cursed the place and since then Palur has been 
called Chowghat, the cursed forest, where a Brahmin can take neither food nor drink. According to Fr. E.R. Hambye, a priest, Palur must also have been a Jewish centre for one of the nearby places is still called 'Jude Kunnu' Palur or the hill of the Jews. The convergence of these various testimonies shows at least that Palur is a place of remote Christian antiquity.

Lastly, all early Christian writers have agreed that Thomas was the Apostle of India. Jerome who wrote in the fourth century of the Christian era observed that the son of God was present in all places, with Thomas in India, with Peter in Rome, with Paul in Ilyria, with Titus in Crete and with Andrew in Achia.

The above evidence tends to establish the presence of Thomas and the existence of the early christian communities in India. However, there is no clear account of Christian activity from the time of the Apostle's martyrdom till the 4th century A.D.

A new trend emerged in the 4th century in the activities of the churches in the south-western part of India relating to the arrival of a large number of Syrian Christians under the dynamic leadership of a merchant called Canai Thomas. They came to India because the Sassanid Emperor of Persia began a persecution of the Christians. This resulted in a large number of them (including a Bishop and clergy) fleeing to the Western Coast of India where the rulers were more tolerant of Christianity. ${ }^{6}$ About 72 families consisting of about 400 members including a Bishop came to Malabar. These Syrian immigrants were treated as the countrymen of Mar Iso (Lord Jesus) and Mar Thoma (Lord Thomas) and as such worthy of the greatest honour and respect. The Syrians and Malabar Christians soon entered into Matrimonial relations and merged into a single community. Thomas of Cana himself married a Christian woman from Malabar .

Thomas and the Syrian Christians were on good terms with the Perumal. ${ }^{7}$ This amicable relationship of Thomas with the Perumal had far-reaching consequences with regard to the status of the Syrian Christians and the prosperity of the Chera kingdom. Thomas became the chief economic advisor of the Perumal, a relationship which brought prosperity to the Chera kingdom. In recognition of his services the Christians were respected by their King. The Christians were expert huntsmen and soldiers. They were held in high esteem by the people. As a result of the presence of the Christian community during this period a prince in Malabar was respected and feared by his neighbours according to the number of Christians he had in his domain. ${ }^{8}$ This beneficient relationship resulted in the growth of the church.

The Syrian liturgy was introduced into the churches. There was a regular flow of priests and bishops coming from Syria. Consequently, a system of church government was evolved in which bishops were to be of foreign extraction but internal administration was carried on by the Archdeacon. This system worked very well until the arrival of the Portuguese in $1498 .^{9}$

Certain interesting observations emerge in the study of the early history of the state of 
Christianity in India. First, it was predominantly a South India phenomenon for the Christians remained isolated in that area (chiefly Malabar and scantily in Tamil Nadu) until the advent of the Europeans. This phenomenon could be largely attributed to the fact that Kerala was on the main sea trading route and the spread of Christianity into the interior was limited.

The second major observation is that the Malabar Christians were from the higher echelons of society. They were respected by the ruling class. Moraes concludes that due to their economic power they were regarded as the equals of the Brahmins and even refused others to touch them. Understandably enough, a community which had attained such a high status would not wish to endanger its position, both economically and socially, by indiscriminate additions to its ranks of persons belonging to the less advanced castes. The church then during the first fifteen centuries remained a closed corporation ${ }^{10}$. This changed with the advent of the foreign missionaries whose methods of conversion as well as the type of converts they recruited were different.

\section{Effects of Portuguese Rule (After 1498)}

The introduction of the Roman Catholic missions was closely identified with the arrival of the Portuguese in India from the year 1498. That same year marked the beginings of the political power of the Portuguese and the ecclesiastical rule of the Roman Catholic Church in India. The Roman Catholics at that time were also called Latin Christians.

The Portuguese captured Goa in 1510, Malacca in 1511 and Ormuz at the mouth of the Persian Gulf in 1513. Albuquerque, the first Portuguese Viceroy of the East realised that a small country like Portugal could not forever supply men because of its small population and that if a Christian dominion was to be perpetuated in the East, it was necessary to have a solid and reliable Christian population on the spot. The first and immediate method adopted to secure this aim was that of deliberate miscegnation. According to Stephen Neill, Albuquerque invited his men to marry the widows and daughters of the defenders of Goa and they were to become Christians. ${ }^{11}$ The second method used to achieve this aim was mass conversions to Christianity.

The Portuguese Christians slowly went beyond the frontiers of Goa to spread Christianity. This process of religious diffusion began with the advent of the Jesuit priests. Amongst the early Portuguese missionaries was St. Fancis Xavier who arrived in Goa in 1542. Francis Xavier did not stay put in Goa but travelled and preached from the Coromandel Coast - the long strip of land lying between Madras and Cape Comorin. This area is presently constituted by the states of Tamil Nadu and Kerala.

The Portuguese concentrated their missionary activities amongst the fishermen known as the Paravars on the Western Coast of India. The method of early Catholic conversion took the 
form of protecting those who had enemies. The Paravars were a typical example of people who suffered from raids of pirates and land raiders. Their request to be protected by the Portuguese was granted on the condition that they accept baptism and regard the King of Portugal as their overlord. The terms were accepted. About ten thousand people were converted and the most probable date was around $1536 .{ }^{12}$

It was not long before the Portuguese discoverd the existence of the ancient church of the Thomas Christians. After an initial spell of cordiality, the relationship between the Thomas Christians and the Latin Christians became strained. Two reasons, one economic and the other religious account for the strained relationship. The Portuguese were trying to establish a monopoly on the pepper trade in Malabar. In order to make this venture a success they needed the economic collaboration of the Thomas Christians who were involved in this particular trade. Unfortunately, the Thomas Christians had trade connections (in the sale of pepper) with the Moors. Thus, the attempt to gain monopoly by the Portuguese proved abortive and this gave rise to friction with the Thomas Christians. Secondly, the Portuguese noticed the different rites of the Syrian Christians and being ignorant of Eastern customs, tried to interfere with them. ${ }^{13}$ Portuguese insensitivity in this regard aggravated the already strained relations.

Strained relations between the Thomas Christians and the Portuguese persisted throughout the 16th and 17th centuries. This finally resulted in two divisions: the Old Church of Syrian Catholics owing allegiance to their own bishops under the Patriarch of Antioch and retaining the use of the Syrian tongue in their services, and the New Church of Jacobites who maintained some dogmas and rites of their own, but were affiliated to Rome. ${ }^{14}$

The method of conversion changed futher with the arrival of new Jesuit priests who began to establish missions in the Eastern Coast of South India by the year 1606. The outstanding missionaries were Robert de Nobili, John de Britlo, Arnauld Carmetle and Beshir. These missionaries made serious attempts in mastering the local languages, customs and ceremonial rites.

A notable example of a Jesuit priest,who posed as an Indian Oriental was Robert de Nobili (sometimes known as the Roman Brahmin). Robert de Nobili made a careful review of the work done by Francis Xavier. He realised that St. Francis's work among the Paravars equated Christianity with the low castes. He attempted a major departure from this scheme of converting the depressed classes only. Robert de Nobili sincerely believed that if he succeeded in converting the high caste Hindus, the others would automatically accept Christianity. This is because he rightly judged the power of the Brahmins as leaders of the religion and social order of the community, and as counsellors of kings. Consequently, he drew up a strategy to incorporate the upper strata of Hindu society into Christianity. Robert de Nobili told everyone he was a Brahmin and started work in Madurai. He did away with all manifestations of western culture and dressed in the fashion of a Sadhu with sandal paste on his 
forehead and a cross hung around his neck. The mission in Madurai that was started by de Nobili flourished and by 1730 recorded a strength of over 200,000 Christians.

Although the early Roman Catholics converted Indians by force, the Jesuits changed their methods. The Jesuits realised that they could convert more people if they permitted Hindu practices amongst converts. They Indianized Christianity. Macnicol noted that

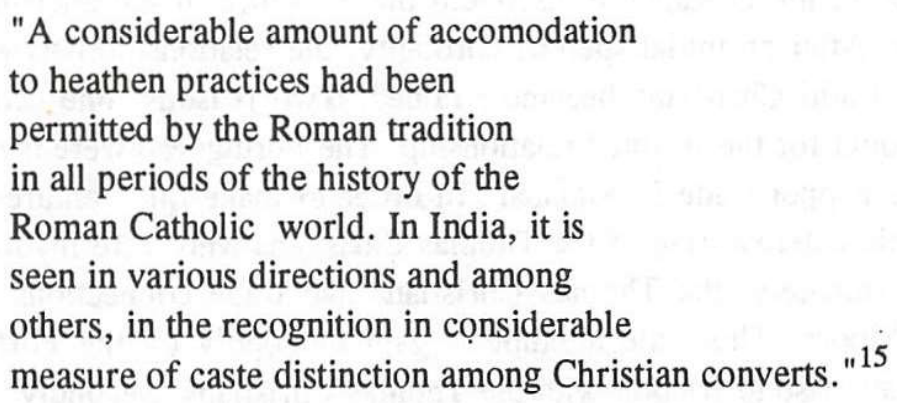

The Jesuit priests were more successful in gaining the support of the lower caste. Abbe Dubois affirms this:

"They (converted Christians) are
found from the lowest of tribes,
so are individuals who, driven
out of their homes on account
of their abuses, are shunned
afterwards by everyone as
outlawed men, and'have no other
resource left than that of
turning Christians in order to
form new connexions in society."

The power of Portugal declined and so did the strength of Roman Catholic Church in India. Thenceforward other countries of Protestant orientation began to play a more important role in the spread of Christianity in India.

\section{Protestant Missions}

The history of Protestant mission activitity in India began in the early part of the 18th century, with the creation of a Danish Lutheran Station at Tranquebar on the Coromandel Coast. This was soon followed by the establishment of other mission centres in areas of South India controlled by the British East India Company, first by missionaries representing the Anglican Society for Promoting Christian Knowlegde, and subsequently by other British organizations such as the London Missionary Society, Church Missionary Society, Church of Scotland Missions, and the Wesleyan Missionary Society. 
Following an amendment of the East India Company Charter in 1833, Christian missionaries were no longer required to obtain a licence to enter the country, and this effectively opened the doors to a wide range of societies based in North America, continental Europe, Australia and elsewhere. Thus, by the end of the 19th century there were in all about 700 missionaries, about 45 Protestant organizations in the South; and about 350,000 adherents. ${ }^{17}$

The method of conversion used by the Protestant Missions was different. Since there were so many societies, they entered into a 'comity'. The rules of the 'comity' required that one society should respect and refrain from entering the 'field of labour' of another. The outcome of this policy was that an area - sometimes only a few villages, at other times corresponding to a large administrative mission - was acknowledged to be the domain of a particular mission society. Thus, for example, South Travancore was the province of the London Missionary Society and the Society for the Propagation of the Gospel; large segments of the North Arcot Area became the province of the Reformed Church in America.

Various methods of conversion were used by these missions. A good example was the estabishment of educational institutions. For instance, the setting up of schools was recognised by the British Missionary society in its original constitution as one of the means adopted for the introduction of Christianity into India. The English language was introduced because it was felt that if the natives were given English education, they might respond more readily to Christianity. The Indian public generally did not oppose missionary schools but they feared the real motives of the missionaries. Gupta says,

"They (Indians) were afraid that
their children if permitted to
attend missionary schools would
be persuaded or even forced to
become Christians. Consequently,
news of conversion of any Indian
to Christianity was greeted with
alarm followed hy a wholesale
withdrawal of students from the
missionary schools. ${ }^{18}$

One method of conversion involves those who become Christians in the context of 'mass movements'. The connotations of this term are not only that it involves a large number of persons but more importantly, the converts in such a movement belong to the same caste within a region so that the adoption of the new religion is more a collective than a personal act. Further, it does not usually entail any siginificant changes in traditional social norms and relationships within a group. As Pickett sugests in his monumental study of Christian mass movements, their characteristic features are group decisions and the consequent preservation of the converts' social integration. ${ }^{19}$ His own estimate is that as many as four-fitths 
of all Protestants in India entered the faith in this way. ${ }^{20}$ The mass conversion enabled the Christians belonging to the same group to reproduce themselves by endogamous marriages and to retain their blood purity. The Christian castes usually marry their own kind. A typical example is the Nadar community.

Hardgrave $^{21}$ describes how Christianity caught on among the Nadars, a distinct and identifiable community from 1784 . The Nadars have been noted for their responsiveness to change and are today one of the most advanced communities in South India. In the 17th century they were considered to be one of the most economically, and socially depressed comunities. By the end of the 19th century, Tirunelveli had the greatest number of Christians in the Madras Presidency, divided about equally between the Roman Catholic and Protestants. Among the Protestants as many as $95 \%$ were Nadars and of the 92 ordained native clergymen, 75 were Nadars.

A number of significant factors caused this particular caste to embrace Christianity. Firstly, the education provided by missionaries played a decisive role. Secondly, Hardgrave suggests that they were overwhelmingly dominant in numbers and had little contact with other castes. Thirdly, they had maintained a high degree of autonomy - a factor which enabled them to respond freely. Finally, they converted in large numbers and, therefore, the fear of being an outcaste in one's own community was absent. In this way they were able to retain caste and religion, i.e. caste and social mobility.

The second and numerically less preponderant manner of conversion involves those who declare for Christ as individuals or in small family groups, generally in defiance or other members of their caste and often therefore, at the cost of their most intimate social ties. Thus in individual conversions, the circumstances of becoming Christians are not so fundametally influenced by considerations of wider group conversion and support. ${ }^{22}$

The Protestant missionaries played a prominent role in conversions and the impact of their activities was felt in many directions. According to Ingham, by 1833, the missionaries had established their position as essential contributors to the development of India. They converted mostly people of low social origins but the effect of the missionary work was felt amongst the higher castes in various ways, particularly in the field of social development. The missionaries though an external force, provided the impetus for social reform in In$\mathrm{dia}^{23}$ The majority were converted through the mass conversion process and had distinct denominational leanings because they had to abide by the rules of 'comity'.

\section{Caste and Social Mobility}

The one dominant feature all through the ages but more prominent during the formation of the Roman Catholic and Protestant churches was the fact that the majority of the converts stemmed from the lower rungs of the Brahmin created Indian social order. This phenome- 
non is significant only if viewed within the framwork of the caste system as caste is very closely associated with social mobility. The term caste is derived from a Portuguese word in reference to the Hindu social groups of pure and undiluted lineage. The castes are divided into 4 great classes, namely, the Brahmins, Ksatriyas, the Vaisyas and the Sudras. The Brahmin belonging to the priestly class, is the head and keystone of the whole scheme. Following him is the Ksatriya belonging to the warrior caste. Then comes the Vaisya or the farmer caste performing various agricultural activities of the land. At the bottom rung are the Sudras providing menial labour for the higher castes. Sudras are sometimes termed as 'pariah' and 'outcaste'. Theoretically. and in accordance with Hindu scriptures, the position of the Sudra would be unalterable.

According to Srinivas, ${ }^{24}$ the idea of caste as division of society, represents a gross over-simplication of facts. The real unit of the caste system, he argues, is not one of the five Varnas, but 'jati' which is a very small endogamous group practising a traditional occupation and enjoying a certain amount of cultural, ritual and juridical autonomy.

There are certain features in the caste system which strengthen the idea of hierarchy. Theological notions such as Karma ${ }^{25}$ and Dharma ${ }^{26}$ have contributed towards this end. The concept of pollution governs relations between different castes. Contact of any kind, touching, dining, sex and other relations between castes which are structurally distant results in the higher of the two caste being polluted. Each caste is traditionally associated with a separate occupation. Any occupation, however, remotely implying the destruction of sentient life in any form would be prohibited to the high castes. The structural features of the caste system would tend to deny lower castes upward social mobility because of theological notions such as dharma, karma and pollution. Nevertheless, right through Indian history there have been ways and means (conscious and unconscious) of gaining upward mobility by low caste groups.

James Silverberg ${ }^{27}$ describes mobility in the Indian community as change in economic, ritual and religious position. He further asserts that they have been able to achieve mobility through the impact of various 'outside' forces that is via factors arising in physico-biological changes or those that are the product of social systems other than the Indian one. An important 'outside' factor that had consequences for Indian social mobility was successful military invasion and conquest. Sometimes, lower-caste Hindus would unite their armed forces with those of the invaders and thus ensure a rise in their own position. A series of unusually good harvests, or the weather or natural disaster, was another kind of outside factor that contributed to upward and downward mobility in Hindu society. Technological change leading to new occupations also operated as a source of social mobility. The introduction of the sewing machine some seventy years ago has led to the emergence of a new caste of 'tailors'.

Although there was social mobility, Silverberg says that the mobility which occurred was 
within an essentially stable, relatively unchanging system. The religious values and ideologies, the kinship system, the localism, the occupational structure, community organizations all these and other essential features of Hindu caste society were able to remain fundamentally the same despite the mobility which occurred. ${ }^{28}$ The mobility that did occur in Hindu India was mobility within a stable order; those who did rise engaged in certain pratices of what has been called 'symbolic justification'. The processes of symbolic justification have been collectively referred to as 'Sanskritization' by Srinivas and other recent scholars who have followed his analysis. A low caste was able, in a generation or two, to rise to a higher position in the hierarchy by Sanskritising its ritual and pantheon. In short, it took over, as far as possible, the customs, rites and beliefs of the Brahmins.

Besides the above avenues of social mobility there have been movements to reorganise society in India through indigenous religions. ${ }^{29}$ Equality rather than hierarchy among all believers was a common theme. Perhaps, initially a person is attracted to a new religion for egalitarian reasons and also to gain status. To cite an example of effective attraction, the report of the 1931 Census in the Punjab noted that many Hindus were becoming Sikhs because they obviously considered that they gained in status as soon as they ceased to be Hindus and became Sikhs. Many were converted to the religion of temporal rulers such as Islam (when Muslims held power) and Christianity (during the British regime). ${ }^{30}$

Buddhism, Jainism and Sikhism accepted all devotees as equal; each wanted no individual social distinctions to be recognised among any of the faithful. ${ }^{31}$ All these indigenous religions provided avenues for social regrouping and their converts also continued to maintain 'Jati' organization. Mandelbaum argues that many could have accepted the introduced religions for essentially spiritual reasons and others were converted because of a desire for social regrouping. The foreign merchants and rulers were too few or too aloof to induct converts into a new way of life as well into a new mode of worship. They offered a reference category rather than a reference group. The converts lacking a new social base to augment their new scripture, therefore, continued in the pervasive caste system. ${ }^{32}$ Mandelbaum concludes that Christian converts were mainly from low social origins, from those who had nothing to lose and perhaps could gain something in status and livelihood. To illustrate this fact he has cited the Nadars as a typical example who sought mobility through conversion.

Almost all the groups that had gained mobility whether through a change in occupation or religion did not abandon the caste system. Nevertheless, the process of regrouping took place. The main reason for the perpetuation of the caste system was that this new group especially the religious group could not stand in isolation. It did not have the social base. But the perpetuation of caste is an apparent contradiction to Christian theological notions of equality. On this basis, it is possible that the caste system may not be as rigid in this new group. 


\section{Conclusion}

The origins of the Indian Christians in India are marked with certain distinctive features. First, Indian Christian missionary efforts. recreated in India the denominational structures of the West. These were the Latin Christians or Roman Catholics, Orthodox Christians and the Protestants who further sub-divided into Methodists, Anglicans and Lutherans. These denominational leanings are also reflected among overseas Indian Christians. Second, the majority of the Indian Christians retained their culture intact. As argued by Mandelbaum earlier, it was merely a regrouping process except that they differed from the Hindus in the God they worshipped and instead of going to the shrine they went to the church. Sunday was marked as a day of worship. Although the life-cycle rites of the Hindus were continued, the church officiated the rites. In other words Christianity was Indianized. ${ }^{33}$ Finally, as was argued earlien, the change to Christianity could have taken place because of a desire to achieve socio-economic mobility. Sopher further reinforces this fact and argues that contact conversion may be stimulated by the anticipation of economic advantages, financial assistance, education, employment or business opportunities. ${ }^{34}$ The perjorative term 'rice Christians' is used for people in the Orient who are thought to have adopted Christianity in areas under European dominance. ${ }^{35}$ One may be led to conclude that conversions to Christianity occurred among the lower caste and marginal Indians. If this were primarily the case, a serious question can be raised: why did not all the members belonging to a depressed community become Christians, Muslims or Sikhs since all these religions theoretically emphasised the equality of men?

Therefore, the reasons for conversion in India cannot be easily distinguished, Nevertheless, J.W. Pickett, in his book, Christian Mass movements in India ${ }^{36}$ gives four possible motives for conversion: (1) Spritual Motives - includes those who seek salvation, trying to know God, to find peace in God and because of faith in Jesus; (2) Secular Motives - this include those who sought the help of missionaries for improved social gathering or to marry a Christian; (3) Social reasons - these include those who are influenced by their peers and who changed their religion to Christianity because their relatives were already Christians; and (4) Natal. influences - these include those who are children of Christian parents.

As a result of all the religious activities of individuals and groups right from the 1st century A.D. to the 20th century, India has a Christian population of $10,726,350$ or $2.44 \%$ (1961 Census figures). ${ }^{37}$ According to Beaglehole, since Independence there has been no question of repeating the large-scale conversion to Christianity which was the characterictic of Christian activity between the wars. The alternative appeal of Buddism to the scheduled caste, the policy of social welfare and its discriminatory administriation have also been reinforced by the atmosphere of hostility to Christian activity. As a result, Beaglehole concludes that the Christian Community in India is adopting an increasingly defensive attitude which threatens to produce not only a ghetto outlook, but also fulfil the verdict of history that new religions that enter India have a good chance of survival but often lose their ability to spread. ${ }^{38}$ 


\section{Bibliography}

Beaglehole, J.H., "The Indian Christian: A Study of a Minority", Modern Asian Studies, Vol.I, pp.59-80

Bose, Devabrata, Problems of Indian Society, Bombay, G.R. Dhatkal, 1968

Caplan, Lionel, "Class and Christianity in South Indian: Indigenous Responses to Western Denominationalism", Modern Asian Studies, Vol. 14, Part 4, Oct. 1980, pp. 645-671

Caplan, Lionel, "Caste and Castelessness Among South Indian Christians", Contributions to Indian Sociology, Vol.14, No.2. 1980, pp.213-238

Chatterton, E., History of the Church of England in India, London, The Macmillan Company, 1924.

Dielh, C.G., Church and Shrine: Intermingling Patterns of Culture in Life of some Christian Groups in South India, Lund, Sweden, 1965

Dubois, Abbe, Letters on the State of Christianity in India, London, Logan, 1823.

Ferroli, D., The Jesuits of Malabar, Bangalore, Bangalore Press, 1939.

Gosal, G.S. \& Mukerjee, A.B., "The religious composition of India's population- A spatial analysis", Tijdchrift Voor Econ En Soc. Geografie - MRT/HPR. 1980

Gupta, K.P.S., The Christian Missionaries in Bengal, Calcutta, K.L. Mukhopadhary, 1971

Hardgrave, R.L., The Nadars of Tamil Nad, Berkeley, University of California Press, 1969

Heres, H., The Conversion Policy of the Jesuits in India, Bombay, Anand Press, 1933.

Ingham, Kenneth, Reformers in India 1799-1833, Cambridge, Cambridge University Press, 1956

Macnicol, N., The Living Religions of the Indian People, London, Student Christian Movement Press, 1934.

Mandelbaum, G., Society in India: Change and Continuity, Vol.2, California .University of California Press, 1970.

Moraes, G.M., A History of Christianity in India, Bonbay, Manaktalas, 1964

Neill, Stephen, The Story of the Christian Church in India and Pakistan, Madras. The Christian Society, 1972.

Neill, Stephen, Colonialism and Christian Missions, London, Lutterworth Press, 1966.

Pickett, J.W., Christian Mass Movements in India, Lucknow, Lucknow Publishing House, 1933.

Silverberg James (ed.), Social Mobility in the Caste System in India, Paris, Mouton Publishers, 1968.

Supher, D.E., Geography of Religions, Englewood Cliffs, Pretice Hall Inc., 1967.

Srinivas. M.N.. Religion and Society Among Coorgs of South India, London, Oxford University Press, 1951.

Thomas, P., Christians and Christianity in India and Pakistan, London, George Allen \& Unwin Lid., 1954. 


\section{Footnotes}

${ }^{1} \mathrm{~A}$ vivid account has been given on this apostle by P. Thomas, Christian and Christianity in India and Pakistan, London, George Allen \& Unwin Ltd., 1954.

${ }^{2}$ The kingdoms of Pandya and Chola were found in the State of Tamil Nadu.

${ }^{3}$ Stephen Neil, The Story of the Christian Church in India and Pakistan, Madras, The Christian Literature Society, 1972, p. 17

${ }^{4}$ Ibid., pp.16-17

${ }^{5}$ G.M. Moraes, A History of Christianity in India Bombay, Mantkalas, 1964, pp. 39-40.

${ }^{6}$ Macnicol, The Living Religions of the Indian People, London, Student Christian Movement Press, 1934, p 269.

${ }^{7}$ Perumal was a titular name for the King of Kerala.

${ }^{8}$ For a more detailed description of the Status of Syrian Christians, see P. Thomas, op.cit., pp. 31-37.

There were also Nestorians and Armenian Christians besides the Syrians but they maintained a low profile.

${ }^{10}$ G.M. Moraes, op.cit., p.23.

${ }^{11}$ Stephen Neill, Colonialism and Christian Missions, London, Lutterworth Press, 1966, pp. 71-74.

${ }^{12}$ Stephen Neill, The Story of the Christian Church in India and Pakistan, Madras, The Christian Literature Society, 1972. p. 33

${ }^{13}$ Ferroli, D., The Jesuits of Malabar, Bangalore, Bangalore Press, 1939, Vol. 1, pp. 101-103.

${ }^{14}$ Herbert, R., George Grierson and William, C., The Ethnology, Languages, Literature and Religions of India, Gurgaon, The Academic Press, 1975, p. 159.

${ }^{15}$ N. Macnicol, op.cit., p. 282.

${ }^{16}$ Abbe Dubios, Letters on the State of Christianity in India, London, Logon, 1823, p.13.

${ }^{17}$ Lionel Caplan, "Class and Christianity in South India: Indigenous Responses to Western Denominationalism", Modern Asian Studies, Vol. 14, Pt. 4, Oct. 1980 pp.646-648.

${ }^{18}$ K.P.S. Gupta, The Christian Missionaries in Bengal, 1793-1833, Culcutta, K.L. Mukhopadhay, 1971, p. 117.

${ }^{19}$ J. Waskom Pickett, Christian Mass Movements in India, Lucknow, Lucknow Publishing House, 1933. p. 22.

${ }^{20}$ Ibid., p. 315.

${ }^{21}$ R.L. Hardgrave, The Nadars of Tamil Nad, Berkeley, University of Califonia Press, 1969, pp. 43-70.

${ }^{22}$ Lionel Caplan, "Caste and Castelessness Among South Indian Christians", Contributions to Indian Sociology, Vol. 14. No.2, 1980, p.218.

${ }^{23}$ Kenneth Ingham, Reformers in India 1799-1833, Cambridge University Press, 1956 p. 122.

${ }^{24}$ See M.N. Srinivas, Religion and Society Among Coords of South India, London, Oxford University Press, 1951, pp. 24 32. 
${ }^{25}$ The idea of karma teaches a Hindu that he is born in a particular sub-caste because he deserves to be born there. The action he performed in a previous incarnation deserved such a reward or punishment as the case might be.

${ }^{26}$ The moral code is identified with Dharma. A man accepts the caste system and the rule of his particular sub-caste in living according to Dharma. If he observes the rules of Dharma, in the next incarnation he will be born into a high caste and viceversa.

${ }^{27}$ James Silverberg (ed.), Social Mobility in the Caste Systems in India, Paris, Mouton Publishers, 1968, pp. 18-35.

${ }^{28}$ Ihid., p. 33.

${ }^{29}$ The indigenous sects are Jainism and Sikhism. Introduced religions are Islam and Christianity.

${ }^{30}$ David G. Mandelbaum, Society in India: Change and Continuity. Vol. II, Berkeley, University of Califonia Press, 1970. p. 524 .

${ }^{31}$ Ibid., p. 533.

${ }^{32}$ Ibid., p. 545

${ }^{33}$ C.G. Diehl, Church and Shrine: Intermingling Patterns of Culture in Life of Some Christian Groups in South India, Lund (Sweden), 1965, pp. 8-11

${ }^{34}$ D.E. Sopher, Geography of Religions, Englewood-Cliffs, Prentic Hall Inc., 1967, pp 90-91.

${ }^{35}$ Ibid., p. 91.

36JJ.W. Pickett, op.cit., p. 161.

${ }^{37}$ Gurdev Singh Gosal \& A.B. Mukerja, "The Religious Composition of India's Population -A Spatial Analysis", Tijdchrift Voor Econ En Soc. Georgrafie - MRT./HPR. 1970, p. 95.

${ }^{38}$ J.H. Beaglehole, "The Indian Christian: A Study Of a Minority", in Moden Asian Studies, Vol. I, 1967, pp. 59-80. 